\title{
Analisis Faktor-faktor yang mempengaruhi Pertumbuhan Ekonomi dan pengaruhnya terhadap Kemiskinan di Kabuparten/Kota Provinsi Jambi
}

\author{
Irmanelly, Ardi Afrizal, Faradilla Herlin \\ Fakultas Ekonomi dan Bisnis Universitas Muhammadiyah Jambi \\ Correspondence email: ardiafrizal1985@gmail.com
}

\begin{abstract}
The first research objective is to analyze export and import factors in influencing economic growth in the District/ City of Jambi Province with partial and simultaneous test results that exports and imports affect economic growth by $12.9 \%$, meaning that if exports and imports increase, economic growth will also increase. increased and evidenced by the significance value below alpha 5\% or $1.8 \%$ and $1.5 \%$. The second research objective is an analysis of economic growth and poverty that in general economic growth has not had a significant effect on poverty in the District/ City of Jambi Province, this can be seen from the calculation of the R-squared value of $1.3 \%$ with a significance level above $10 \%$ or alpha $61,42 \%$.
\end{abstract}

Key words: economic growth, exports, imports, and poverty

\section{Pendahuluan}

Pertumbuhan ekonomi bertujuan untuk meningkatkan kesejahteraan masyarakat bahwa pertumbuhan ekonomi yang kondusif dapat meningkatkan kemampuan social ekonomi masyarakat di suatu negara. Sehingga seluruh penduduk dapat memperoleh kesempatan yang sama untuk menikmati hasil pertumbuhan ekonomi, karena pertumbuhan ekonomi dapat meningkatkan kesejateraan masyarakat melalui peningkatan pendapatan. (Amalia, 2019). Sementara Boediono (2012) bahwa proses pertumbuhan adalah kenaikan output perkapita. Pandangan lain Jhingan (2003) bahwa pertumbuhan ekonomi adalah kenaikan jangka panjang dalam kemampuan suatu negara (daerah) untuk menyediakan barang ekonomi kepada penduduknya melalui kemajuan teknologi. Sudut pandang pertumbuhan ekonomi akan dilihat dari Produk Domestik Regional Bruto (PDRB).

Perekonomian dikatakan mengalami pertumbuhan apabila jumlah balas jasa riil terhadap penggunaan faktor-faktor produksi pada tahun tertentu lebih besar dari pada tahun sebelumnya. Pertumbuhan ekonomi dianggap sebagai faktor penting dalam kehidupan manusia, tetapi tidak secara otomatis akan mempengaruhi peningkatan martabat dan harkat manusia. Dalam hubungan ini, ada tiga komponen yang dianggap paling menentukan dalam pembangunan, umur panjang dan sehat, perolehan dan pengembangan pengetahuan, dan peningkatan terhadap akses untuk kehidupan yang lebih baik. Tikson, (2005). Menurut Todaro dan Smith dikutip dari Kumalasari, (2006) bahwa pertumbuhan ekonomi adalah salah satu indikator yang digunakan untuk mengukur prestasi ekonomi suatu negara atau daerah. Salah satu faktor yang mempengaruhi pertumbuhan ekonomi adalah melalui kegiatan ekspor dan impor. Dimana ekspor adalah penjualan barang ke luar negeri melalui permintaan ekspor dari jumlah barang/jasa yang diminta dari suatu negara ke negara lain (Sukirno, 2010). Proses ekspor pada umumnya adalah tindakan untuk mengeluarkan barang atau komoditas dari dalam negeri untuk memasukannya ke negara lain. Krugman, (2005). Dalam Mankiw (2009), bahwa berbagai faktor yang dapat mempengaruhi ekspor dan impor suatu negara dimana impor adalah kegiatan memasukkan barang ke dalam daerah melalui kegiatan perdagangan dengan cara memasukkan barang dari luar negeri ke dalam daerah dengan mematuhi ketentuan peraturan perudang-undangan yang berlaku. (Tandjung, 2011). Menurut Susilo (2008) bahwa impor diartikan sebagai kegiatan memasukkan barang dari suatu negara (luar negeri) ke dalam wilayah negara lain atau melibatkan dua negara. Menurut Purnamawati (2013) impor adalah membeli barang-barang dari luar negeri sesuai dengan ketentuan pemerintah yang dibayar dengan menggunakan valuta asing.

Hal yang berbeda menurut penelitian Malik dkk (2020) bahwa ekspor tidak berpengaruh signifikan terhadap pertumbuhan ekonomi sedangkan sedangkan untuk impor memiliki pengaruh signifikan terhadap pertumbuhan ekonomi. Sementara pandangan Purba, (1983) bahwa kegiatan impor adalah melalui perdagangan internasional dengan cara memasukkan barang melalui perorangan atau perusahaan dengan mematuhi ketentuan peraturan perundang-undangan yang berlaku. Sedangkan menurut Diniar (2014) mengatakan apabila distribusi pendapatan yang tinggi akan menciptakan perubahan, perbaikan dan kesempatan untuk meningkatkan kemakmuran masyarakat seperti mengurangi kemiskinan, pengangguran, menekan kesenjangan dan kesulitan ekonomi sosial lain dalam masyarakat. Sebaliknya jika distribusi pendapatan nasional atau suatu daerah tidak merata, tidak akan menciptakan kesejahteraan sosial bagi seluruh lapisan masyarakat. Artinya, sangat penting upaya untuk terus melakukan meningkatkan pertumbuhan ekonomi nasional atau suatu provinsi/kabupaten. 
Irmanelly et al., Analisis Faktor-faktor yang mempengaruhi Pertumbuhan Ekonomi dan pengaruhnya terhadap Kemiskinan di Kabuparten/Kota Provinsi Jambi

Hal itu dibuktikan dari penelitian Triani (2018) bahwa kemiskinan mempunyai pengaruh yang signifikan terhadap pertumbuhan ekonomi artinya apabila kemiskinan meningkat maka pertumbuhan ekonomi akan menurun. Sementara menurut penelitian Budhijana (2017) bahwa pertumbuhan ekonomi tidak berpengaruh negatif signifikan terhadap tingkat kemiskinan. Salah satu permasalahan perekonomian adalah terkait dengan kemiskinan dimana kemiskinan adalah suatu keadaan dimana seseorang tidak sanggup memelihara dirinya sendiri dengan taraf kehidupan yang dimiliki dan juga tidak mampu memanfaatkan tenaga mental maupun fisiknya untuk memenuhi kebutuhannya (Arsyad, 2010). Sementara menurut Henrik, (2005) permasalahan negara berkembang menyangkut pengembangan sumber-sumber yang belum dioptimalkan. Sedangkan Febriana (2010) memberikan penjelasan bahwa kemiskinan merupakan persoalan individu yang merupakan akibat dari pilihan-pilihan individu. Skema terbentuknya kemiskinan yang didasarkan pada konsep Chambers menerangkan bagaimana kondisi yang disebut miskin di sebagian besar negara-negara berkembang dan dunia ketiga adalah kondisi yang disebut memiskinkan. Kondisi yang sebagian besar ditemukan bahwa kemiskinan selalu diukur/diketahui berdasarkan rendahnya kemampuan pendapatan dalam memenuhi kebutuhan-kebutuhan pokok berupa pangan, kesehatan, perumahan atau pemukiman, dan pendidikan.

Kemiskinan adalah konsep yang relatif, bagaimana cara kita mengukurnya secara obyektif dan bagaimana cara kita memastikan bahwa ukuran kita dapat diterapkan dengan tingkat relevasi yang sama dari waktu ke waktu. Untuk mengukur kemiskinan ada tiga indikator yang diperkenalkan (Tambunan, 2009) yang sering digunakan di dalam banyak studi empiris. Pertama, the incidence of poverty: persentase dari populasi yang hidup di dalam keluarga dengan pengeluaran konsumsi per kapita di bawah garis kemiskinan. Kedua, the depth of poverty yang menggambarkan dalamnya kemiskinan di suatu wilayah yang diukur dengan indeks jarak kemiskinan (IJK), atau dikenal dengan sebutan poverty gap index. Ketiga, the severity of poverty yang diukur dengan indeks keparahan kemiskinan (IKK).

Bila pendapatan tidak dapat mencapai kebutuhan minimum, maka orang dapat dikatakan miskin, dengan demikian kemiskinan diukur dengan memperbandingkan tingkat pendapatan orang dengan tingkat pendapatan yang dibutuhkan untuk memperoleh kebutuhan dasarnya. Tingkat pendapatan minimum merupakan pembatas antara keadaan miskin dengan tidak miskin atau sering disebut sebagai garis batas kemiskinan. Todaro (2003); Arsyad (2004). Pendapat lain Arsyad (2004) bahwa walaupun pendapatan sudah mencapai tingkat kebutuhan dasar minimum tetapi masih jauh lebih rendah dibandingkan dengan keadaan masyarakat disekitarnya, maka orang tersebut masih berada dalam keadaan miskin. Hal ini terjadi karena kemiskinan lebih banyak ditentukan oleh keadaan sekitarnya dari pada lingkungan orang yang bersangkutan. Ukuran kemiskinan relatif sangat tergantung pada distribusi pendapatan/pengeluaran penduduk bahwa kemiskinan dihitung melalui pendekatan pendapatan. Pendekatan pendapatan untuk mengukur kemiskinan ini mengasumsikan bahwa seseorang dan rumah tangga dikatakan miskin jika pendapatan atau konsumsi minimumnya berada di bawah garis kemiskinan. Kemiskinan sebagai persoalan individu, melainkan lebih melihatnya sebagai persoalan struktural (Febriana, 2010) ketidakadilan dan ketimpangan dalam masyarakatlah yang mengakibatkan kemiskinan ada dalam masyarakat.

Hal yang berbeda dari kondisi pertumbuhan ekonomi dan kemiskinan di Kabupaten/ Kota Provinsi Jambi yang mengalami fluktuasi yang cukup dinamis selama tahun 2014-2019. Dimana untuk jumlah penduduk miskin paling tinggi terdapat di Kota Jambi yaitu rata-rata sebesar 51,62 (ribu jiwa) sedangkan untuk penduduk miskin paling sedikit terdapat di wilayah Kota Sungai Penuh yaitu rata- rata sebesar 2,68 (ribu jiwa). Namun jika dilihat dari nilai rasio pertumbuhan ekonomi justru Kota Sungai Penuh paling rendah pengaruhnya terhadap kemiskinan dibandingkan Kota Jambi yaitu sebesar 0,55 dan 8,21. Kemudian secara akumulasi dapat terlihat bahwa jumlah penduduk miskin di Provinsi Jambi adalah rata-rata sebesar 285.805 (ribu jiwa). Artinya jika dihubungkan dengan laju pertumbuhan ekonomi di Kabupaten/ Kota Provinsi Jambi menjelaskan bahwa pertumbuhan ekonomi yang tinggi belum tentu berbandingan sama dalam pengurangan angka kemiskinan seperti yang terjadi di Kota Sungai Penuh dimana merupakan wilayah dengan pertumbuhan ekonomi tertinggi selama 6 tahun terakhir periode 2014-2019 yaitu sebesar 6,29\% dan diikuti laju pertumbuhan ekonomi terendah terdapat di Kabupaten Tanjung Jabung Timur yaitu rata-rata sebesar 3,30\%.

Sementara faktor lain yang mempengaruhi pertumbuhan ekonomi adalah dengan kegiatan ekspor dan impor. Artinya jika ekspor mengalami surplus maka pertumbuhan ekonomi akan meningkat sementara impor tergantung kepada jenis barang dan jasa yang sangat dibutuhkan dari kegiatan masyarakat. Secara akumulasi volume akspor di Provinsi Jambi adalah rata-rata sebesar 5.595.924,7 (ton) sedangkan untuk volume impor adalah rata-rata sebesar $176.117,33$ (ton). Secara umum volume ekspor jauh lebih besar dari volume impor dimana pada tahun 2014 perbandingan volume ekspor sebesar 6.848 .319 (ton), 2015 sebesar 6.886.252 (ton), 2016 sebesar 6.159 .062 (ton), 2017 sebesar menurun menjadi 4.171 .394 (ton), 2018 sebesar 4.786 .883 (ton) dan 2019 volume ekspor mengalami penurunan menjadi 3.666.934 (ton). Berdasarkan fenomena yang dijelaskan diatas bahwa bagaimana faktor-faktor seperti ekspor dan impor mempengaruhi pertumbuhan ekonomi di Kabupaten/ Kota Provinsi Jambi periode 2014-2019 dan bagaimana pengaruh pertumbuhan ekonomi terhadap kemiskinan di Kabuapten/Kota Provinsi Jambi periode 2014-2019. 
Irmanelly et al., Analisis Faktor-faktor yang mempengaruhi Pertumbuhan Ekonomi dan pengaruhnya terhadap Kemiskinan di Kabuparten/Kota Provinsi Jambi

\section{Metode}

Metode penelitian ini melalui pendekatan analisis deskripif kuantitatif. Metode pengolahan data yang digunakan melalui regresi data panel dengan uji Common Effect Model. Adapun jenis data yang digunakan dalam penelitian ini adalah data sekunder, seperti data pertumbuhan ekonomi, kemiskinan, ekspor dan impor. Sedangkan untuk sumber data yang diperoleh dari penelitian ini adalah BPS, jurnal dan publikasi ilmiah lainnya. Cammon Effect Model (CEM) mengasumsikan tidak ada perbedaan efek sektor maupun waktu, sehingga dalam permodelannya hanya terdapat satu model untuk seluruh pengamatan. Tekhnik estimasi Cammon Effect Model (CEM) yaitu melalui ordinary Least Squares (OLS):

$Y_{i t}=\alpha+\sum_{j=1}^{p} Q_{j} X_{j i t}+S_{i t}$

Formulasi Cammon Effect Model (CEM) dapat diturunkan kedalam persamaan regresi data panel yang bertujuan untuk menganalisis faktor- faktor yang mempengaruhi pertumbuhan ekonomi di Kabupaten/ Kota Provinsi Jambi periode 2014-2019, maka dapat diformalasikan sebagai berikut:

$Y_{i t}=\alpha_{i}+X_{i t}^{\prime} Q+S_{i t}$ atau $Y_{i t p e}=\alpha_{i}+X_{i t}^{\prime} Q_{e k s}+X_{i t}^{\prime} Q_{i m p}+S_{i t}$

$Y_{i t p e}=$ Pertumbuhan ekonomi; $\alpha=$ Konstanta; $\beta=$ Koefisien Variabel; $\mathrm{s}_{1}, \mathrm{~s}_{2}$, = Disturbansi atau gangguan skokastik; $\beta_{\text {eks }}=$ Ekspor $; \beta_{\text {imp }}=$ Impor; $\beta_{\text {imp }}=$ Impor

Sedangkan untuk menganalisis pengaruh pertumbuhan ekonomi terhadap kemiskinan di Kabuapten/ Kota Provinsi Jambi periode 2014-2019, maka dapat diformalasikan sebagai berikut:

$Y_{i t}=\alpha_{i}+X^{\prime} Q+S_{i t}$ atau $Y_{i t k m s}=\alpha_{i}+X^{\prime} Q_{p e}+S_{i t}$

$Y_{i t k m s}=$ Kemiskinan; $\alpha=$ Konstanta; $\beta=$ Koefisien Variabel; $S_{i t}=$ Disturbansi atau gangguan skokastik; $\beta_{p e}=$ Pertumbuhan ekonomi

\section{Hasil}

Tabel 1

Hasil Perhitngan Faktor-faktor yang Mempengaruhi Pertumbuhan Ekonomi di Kabupaten/Kota Provinsi Jambi Periode 2014-2019

\begin{tabular}{|l|r|r|r|r|}
\hline \multicolumn{1}{|c|}{ Variable } & \multicolumn{1}{c|}{ Coefficient } & \multicolumn{1}{c|}{ Std. Error } & \multicolumn{1}{c|}{ t-Statistic } & Prob. \\
\hline C & 5.039615 & 0.933146 & 5.400673 & 0.0000 \\
\hline X1 & $4.13 \mathrm{E}-07$ & $1.70 \mathrm{E}-07$ & 2.437015 & 0.0180 \\
\hline X2 & $-1.15 \mathrm{E}-05$ & $4.61 \mathrm{E}-06$ & -2.484262 & \\
\hline R-squared & 0.126183 & Mean dependent var & & \\
\hline Adjusted R-squared & 0.095523 & S.D. dependent var & & \\
\hline S.E. of regression & 1.502877 & Akaike info criterion & & 3.333333 \\
\hline Sum squared resid & 128.7424 & Schwarz criterion & & 3.701346 \\
\hline Log likelihood & -108.0404 & Hannan-Quinn criter. & & 3.742306 \\
\hline F-statistic & 4.115526 & Durbin-Watson stat & & \\
\hline Prob(F-statistic) & 0.021403 & & & \\
\hline Sumbr: & & & \\
\end{tabular}

Sumber: Data olahan

Hasil perhitungan regresi linear berganda dengan penggunaan data panel diperoleh nilai fungsi sebagai berikut: $\mathrm{Y}_{\mathrm{it}}=5,039615+0,0180 \mathrm{Q}_{\mathrm{eks}}+0,0159 \mathrm{Q}_{\mathrm{imp}}$

Hasil perhitungan regresi linear berganda bahwa eskpor dan impor memiliki pengaruh terhadap pertumbuhan ekonomi di Kabupaten/ Kota Provinsi Jambi sebesar 12,9\% dengan signifikansinya dibawah alpha 5\% yaitu sebesar 1,8\% untuk ekspor dan 1,5\% untuk impor. Kemudian hasil uji secara parsial dan simultan bahwa ekspor dan impor memiliki pengaruh sangat signifikan terhadap pertumbuhan ekonomi dengan nilai alpa dibawah $5 \%$ atau $0,0 \%$ dan $2,1 \%$ artinya jika ekspor dan impor meningkat maka pertumbuhan ekonomi juga meningkat hal itu terlihat dari nilai konstanta sebesar 5,039615. Sesuai dengan teori Todaro dan Smith mengatakan bahwa tingginya pertumbuhan ekonomi suatu wilayah maka semakin baik kegiatan ekonomi. 
Irmanelly et al., Analisis Faktor-faktor yang mempengaruhi Pertumbuhan Ekonomi dan pengaruhnya terhadap Kemiskinan di Kabuparten/Kota Provinsi Jambi

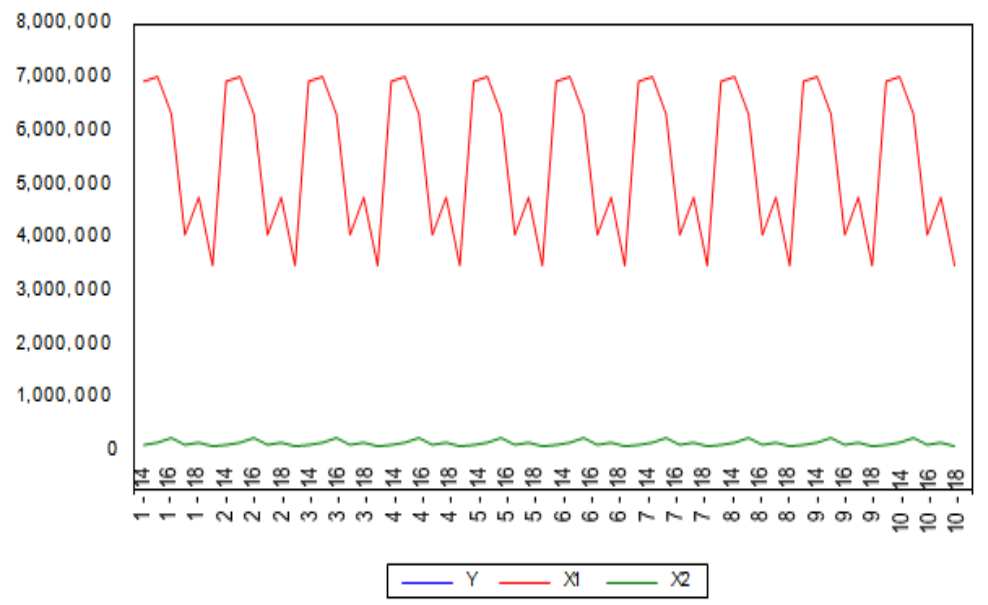

Sumber: data olahan

\section{Gambar 1}

Fluktuasi Ekspor dan Impor di Kabupaten/ Kota Provinsi Jambi

Tabel 2

Hasil Perhitngan Pengaruh Pertumbuhan Ekonomi Terhadap Kemiskinan di Kabupaten/Kota Provinsi Jambi Periode 2014-2019

\begin{tabular}{|l|r|l|r|r|}
\hline \multicolumn{1}{|c|}{ Variable } & Coefficient & \multicolumn{1}{c|}{ Std. Error } & t-Statistic & \multicolumn{1}{c|}{ Prob. } \\
\hline C & 5.039782 & 0.614502 & 8.201415 & 0.0000 \\
\hline X1 & 0.010367 & 0.020454 & 0.506830 & 0.6142 \\
\hline R-squared & 0.004409 & Mean dependent var & & \\
\hline Adjusted R-squared & -0.012756 & S.D. dependent var & & \\
\hline S.E. of regression & 1.590292 & Akaike info criterion & & 3.333333 \\
\hline Sum squared resid & 146.6837 & Schwarz criterion & & 3.8682478 \\
\hline Log likelihood & -111.9543 & Hannan-Quinn criter. & & 3.825785 \\
\hline F-statistic & 0.256876 & Durbin-Watson stat & & \\
\hline Prob(F-statistic) & 0.614196 & & & \\
\hline Sumber: Data & & & \\
\end{tabular}

Sumber: Data olahan

Hasil perhitungan regresi linear berganda dengan penggunaan data panel diperoleh nilai fungsi sebagai berikut: $\mathrm{Y}_{\text {it }}=5,039782+0,06142 \mathrm{X}_{1}$

Hasil perhitungan regresi linear sederhana bahwa secara umum pertumbuhan ekonomi memiliki pengaruh yang sangat rendah terhadap kemiskinan di Kabupaten/ Kota Provinsi Jambi hal itu dibuktikan dari nilai R- squared sebesar 1,3\% dan tidak signifikan karena berada diatas alpha $10 \%$ atau sebesar $61,42 \%$. Namun uji secara parsial bahwa pertumbuhan ekonomi memiliki pengaruh terhadap kemiskinan terlihat dari nilai alpa dibawah $5 \%$ yaitu $0,0 \%$, artinya jika pertumbuhan ekonomi meningkat $1 \%$ maka kemiskinan akan turun sebesar 5,04\%. Hasil penelitian ini sesuai dengan teori trickle-down effect yang menjelaskan bahwa pertumbuhan ekonomi akan diikuti oleh aliran vertikal dari penduduk kaya ke penduduk miskin yang terjadi dengan sendirinya. Oleh sebab itu, maka dapat disimpulkan bahwa pertumbuhan ekonomi dapat berdampak positif bagi pengurangan kemiskinan bila mana pertumbuhan ekonomi yang terjadi berpihak pada penduduk miskin. Untuk melihat fluktuasi pertumbuhan ekonomi dan kemiskinan di Kabupaten/ Kota Provinsi Jambi terlihat pada gambar 2 sebagai berikut: 
Irmanelly et al., Analisis Faktor-faktor yang mempengaruhi Pertumbuhan Ekonomi dan pengaruhnya terhadap Kemiskinan di Kabuparten/Kota Provinsi Jambi

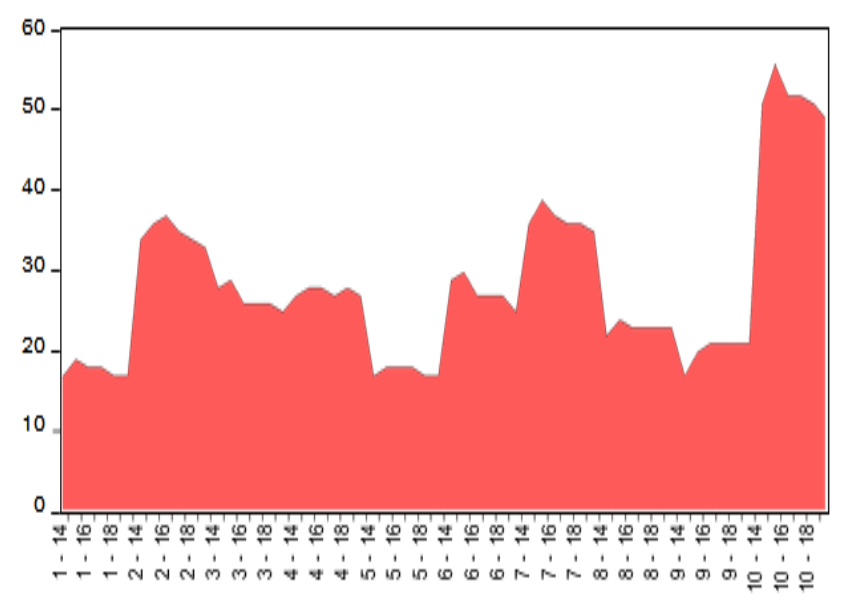

Sumber: data olahan

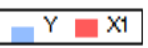

Gambar 2

Fluktuasi Pertumbuhan Ekonomi dan Kemiskinan di Kabupaten/Kota Provinsi Jambi

\section{Simpulan}

Hasil perhitungan analisis eskpor dan impor terhadap pertumbuhan ekonomi di Kabupaten/Kota Provinsi Jambi dimana memiliki pengaruh sebesar 12,9\% dan signifikan dengan nilai alpa dibawah $5 \%$ atau $0,0 \%$ dan $2,1 \%$ artinya jika ekspor dan impor meningkat maka pertumbuhan ekonomi juga meningkat hal itu terlihat dari nilai konstanta sebesar 5,039615. Hasil perhitungan analisis pertumbuhan ekonomi terhadap kemiskinan di Kabupaten/ Kota Provinsi Jambi memiliki pengaruh yang sangat rendah terbukti dari nilai R-squared sebesar 1,3\% dan tidak signifikan dengan nilai berada diatas alpha $10 \%$ atau sebesar $61,42 \%$. Namun secara parsial pertumbuhan ekonomi memiliki pengaruh terhadap kemiskinan terlihat dari nilai alpa dibawah $5 \%$ atau $0,0 \%$, artinya jika pertumbuhan ekonomi meningkat $1 \%$ maka kemiskinan akan turun sebesar 5,04\%.

\section{Daftar Pustaka}

Afyana Afdal dan Mike Triani, 2018. Analisis Faktor-Faktor yang Mempengaruhi Pertumbuhan Ekonomi di Kab/Kota Sumatera Barat. Jurusan Ilmu Ekonomi Fakultas Ekonomi Universitas Negeri Padang

Amalia, F. 2013. Hubungan Kausalitas Investasi dengan Pertumbuhan Ekonomi Indonesia, 2(1), 1-16.

Akhmad, 2007. Ukuran-Ukuran Kemiskinan. Head Count Index. Jakarta

Arsyad Lincolin, 2010. Ekonomi Pembangunan, Edisi 5. Unit Penerbit dan Percetakan.UGM.

Astuti Purnamawati, 2013. Dasar-Dasar Ekspor Impor. Sinar Grafindo

Boediono, 2012. Teori Pengantar Ilmu Ekonomi. BPFE, Yogyakarta

Diniar Rahmawaty, 2014. Analisis Faktor yang Mempengaruhi Ketimpangan spasial Kabupaten/Kota di Provinsi Banten Tahun 2001-2013. Semarang

Deddy T. Tikson. 2005. Indikator-indikator Pembangunan Ekonomi. Pustaka Sinar Harapan. Jakarta

Enny Febriana, 2010. Pedesaan Dalam Perspektif Kemiskinan Berkelanjutan. FE UI. Jakarta

Hendra Kusuma, Fidanti Pramay Sheilla dan Nazaruddin Malik, 2020. Analisis Pengaruh Ekspor dan Impor Terhadap Pertumbuhan Ekonomi (Studi Perbandingan Indonesia dan Thailand). Universitas Muhammadiyah Malang

Jhingan, M. L, (2003). Ekonomi Pembangunan dan Perencanaan. PT. Raja Grafindo Persada. Jakarta

Kumalasari, Merna, 2011. Potret Ketertinggalan Sumber daya Manusia di Kawasan dan Pertumbuhan Ekonomi Regional di Indonesia. Media. www.depnakernas.go.id

Krugman, Paul R. dan Maurice Obstfeld, 2005, Ekonomi Internasional Teori dan Kebijakan. edisi 5 jilid 2, PT.Indeks kelompok Gramedia. Jakarta

Mankiw N. Gregory \& Matthew Weinzierl \& Danny Yagan, 2009. Optimal Taxation In Theory And Practice. Journal Of Economic Perspectives, American Economic Association, Vol. 23(4)

Miller Rogeer LR, Meiners, 2000 dalam Arsyad Lincolin, (2004). Ekonomi Pembangunan. -Ed. 3. PT Rineka Cipta. Jakarta.

R. Bambang Budhijana, 2017. Analisis Pengaruh Pertumbuhan Ekonomi, Index Pembangunan Manusia (IPM) dan Pengangguran Terhadap Tingkat Kemiskinan di Indonesia Tahun 2000-2017. STIE Indonesia Banking School

Susilo Andi, 2008. Ekspor-Impor. Trans Media Pustaka. Yogyakarta

Sadono Sukirno, 2010. Makroekonomi Teori Pengantar Edisi Ketiga, PT Raja Grafindo Persada. Jakarta. 
Irmanelly et al., Analisis Faktor-faktor yang mempengaruhi Pertumbuhan Ekonomi dan pengaruhnya terhadap Kemiskinan di Kabuparten/Kota Provinsi Jambi

Tandjung Marolop, 2011. Aspek dan Prosedur Ekspor-Impor. Salemba Empat. Jakarta

Tambunan Tulus T.H. 2009, Perekonomian Indonesia. Penerbit Ghalia Indonesia Ciawi-Bogor.

Todaro dalam Michael P, \& Stephen C. Smith, 2003. Economic Development. Eight Edition, England Pearson Education Limited

Todaro P. M, \& Stephen. C. S, (2006). Pembangunan Ekonomi. Penerbit Erlangga. Jakarta

Purba Radiks, 1983. Pengetahuan Perdagangan Luar Negeri Indonesia. Pustaka. Jakarta

Van Den Berg dan Henrik, 2005. Economic Growth and Development. Mcgraw- Hill. Singapore 